\title{
PENGEMBANGAN PERANGKAT PEMBELAJARAN KIMIA MENGGUNAKAN MODEL PEMBELAJARAN KOOPERATIF TIPE STAD BERBASIS MULTIPLE REPRESENTASI UNTUK MENINGKATKAN HASIL BELAJAR SISWA PADA POKOK BAHASAN REAKSI REDUKSI OKSIDASI DI KELAS X SMA
}

\author{
Heri Susanto $^{1)}$, Suyatno ${ }^{2)}$, Madlazim ${ }^{3)}$ \\ 1) Mahasiswa Program Pendidikan Sains, Program Pascasarjana Universitas Negeri Surbaya \\ ${ }^{2), 3)}$ Dosen Program Pascasarjana Universitas Negeri Surbaya \\ E-mail: ayahnyaigo@gmail.com
}

\begin{abstract}
This research aims to develop a feasible, practical, and effective instructional material with cooperative learning model of STAD type using multiple representations to improve learning outcomes of senior high school students. This research is the developmental research, using four D models. Limited tryout of teaching material used one-group pretest-posttest design. This research used a sample of senior high school students of class X Trimurti Surabaya academic year 2013/2014 on oxidation reduction reaction topic. The results were obtained: (1) the validity of the content of the lesson plans, student book, work sheet, learning outcome test were good category; (2) the readability of student book and work sheet were good category; (3) learning performance were good category; (4) students activity showed to students centered learning; (5) students gave the positive response to learning process; (6) all students achieved mastery of learning with high gain scores. Based on the results of this research it could be concluded that the Chemistry teaching material with cooperative learning model of STAD type using multiple representations to improve the students learning outcomes of senior high school students on the oxidation reduction reaction were feasible, practical, and effective to be used at learning process.
\end{abstract}

Keywords: cooperative learning model of STAD type, multiple representation

\begin{abstract}
Abstrak: Penelitian ini bertujuan untuk mengembangkan perangkat pembelajaran yang layak, praktis, dan efektif dengan menggunakan model pembelajaran kooperatif tipe STAD berbasis multiple representasi untuk meningkatkan hasil belajar siswa di kelas X SMA. Penelitian pengembangan menggunakan model 4-D dengan menggunakan rancangan one group pretest-posttest design. Sampel dalam penelitian adalah siswa kelas X SMA Trimurti Surabaya tahun pelajaran 2013/2014 untuk pokok bahasan reaksi reduksi oksidasi. Hasil penelitian menunjukkan: (1) validitas isi RPP, BAS, LKS, THB aspek pengetahuan berkategori baik; (2) tingkat keterbacaan BAS dan LKS berkategori baik; (3) keterlaksanaan RPP berkategori baik; (4) aktivitas siswa menunjukkan pembelajaran yang berpusat pada siswa; (5) respon siswa positif terhadap proses pembelajaran; (6) seluruh siswa mencapai ketuntasan hasil belajar dengan skor peningkatan yang tinggi. Berdasarkan hasil penelitian ini, dapat disimpulkan bahwa perangkat pembelajaran Kimia dengan model pembelajaran kooperatif tipe STAD berbasis multiple representasi untuk meningkatkan hasil belajar siswa pada pokok bahasan reaksi reduksi oksidasi di kelas X SMA layak, praktis, dan efektif digunakan dalam pembelajaran.
\end{abstract}

Kata kunci: pengembangan perangkat pembelajaran, model pembelajaran kooperatif tipe STAD, multiple representasi

\section{PENDAHUluAN}

Fokus studi tentang belajar dan mengajar bidang kimia lebih ditekankan pada interkoneksi di antara ketiga level representasi yaitu level representasi makroskopik, submikroskopik, dan simbolik (Johnstone, 2000).. Representasi makroskopik dideskripsikan sebagai representasi kimia yang diperoleh melalui pengamatan nyata terhadap suatu fenomena yang dapat dilihat dan dipersepsi oleh panca indra baik secara langsung maupun tak langsung.
Representasi submikroskopik merupakan representasi kimia yang menjelaskan dan mengeksplansi mengenai struktur dan proses pada level partikular (atom/molekul) terhadap fenomena makroskopik yang diamati. Mode representasi pada level ini dapat diekspresikan mulai dari yang sederhana hingga menggunakan teknologi komputer, yaitu menggunakan kata-kata, diagram/gambar, model dua dimensi, model tiga dimensi baik diam maupun bergerak. Representasi simbolik yaitu representasi kimia secara kualitatif dan 
kuantitatif, yaitu rumus kimia, diagram, gambar, persamaan reaksi, stoikiometri, dan perhitungan matematik (Gilbert dan Treagust, 2009).

Penelitian mengenai multiple representasi dilakukan oleh Sunyono, yang mengembangkan model pembelajaran berbasis multiple representasi dan kemudian diterapkan di kelas untuk pembelajaran kimia dasar dengan topik stoikiometri dan struktur atom, dalam penelitiannya ini menghasilkan tingkat kepraktisan (keterlakasanaan dan kemenarikan) serta keefektifan yang tinggi dalam membangun model mental dan meningkatkan penguasaan konsep kimia mahasiswa (Sunyono 2014). Penelitian lain dilakukan oleh Herawati, yang menyatakan bahwa prestasi belajar siswa dengan pembelajaran multiple representasi pada materi pokok laju reaksi lebih tinggi daripada pembelajaran konvensional (Herawati. $d k k$, 2013).

Penggunaan aspek multiple representasi sangat diperlukan guru dalam proses pembelajaran kimia di kelas. Guru dapat merancang model pembelajaran dengan mengimplementasikan aspek multiple representasi, agar efektivitas model pembelajaran yang digunakan meningkat. Penelitian ini mengkombinasikan penggunaan aspek multiple representasi dengan model pembelajaran kooperatif tipe STAD. Pokok bahasan materi reaksi redoks yang dipelajari di kelas $\mathrm{X}$ tepat apabila dalam proses pembelajarannya menggunakan model pembelajaran multiple representasi, di dalam materi redoks terdapat konsep abstrak maupun konkret yang dapat diamati secara visual. Penyajian materi redoks lebih lanjut diperlukan gambaran lengkap mengenai aspek multiple representasi (makroskopik, submikroskopik, dan simbolik).

\section{METODE PENELITIAN}

Jenis penelitian ini adalah penelitian pengembangan karena dikembangkan perangkat pembelajaran Kimia dengan model pembelajaran kooperatif tipe STAD berbasis multiple representasi untuk meningkatkan hasil belajar siswa pada pokok bahasan reaksi reduksi oksidasi di kelas X SMA. Perangkat pembelajaran yang dikembangkan terdiri dari Rencana Pelaksanaan Pembelajaran (RPP), Buku Ajar Siswa (BAS), Lembar Kegiatan Siswa (LKS), dan Tes Hasil Belajar (THB). Subyek penelitian ini adalah perangkat pembelajaran Kimia yang telah dikembangkan yaitu RPP, BAS, LKS, dan THB yang diterapkan pada 31 siswa kelas X SMA Trimurti Surabaya semester genap tahun pelajaran 2013/2014, dengan rancangan penelitian yang digunakan One Group Pre Test and Post Test Design (Arikunto, 2002). Dengan pola sebagai berikut:

$$
\mathrm{O}_{1} \mathrm{X} \quad \mathrm{O}_{2}
$$

Keterangan:

$\mathrm{O}_{1}$ : Pengujian awal (pre test) sebelum pemberian perlakuan

$\mathrm{O}_{2}$ : Pengujian akhir (post test) setelah pemberian perlakuan

$\mathrm{X}$ : Perlakuan dengan menggunakan model pembelajaran kooperatif tipe STAD berbasis multiple representasi.

Tahapan penelitian dibagi menjadi dua tahap, yaitu tahap pengembangan perangkat pembelajaran dan tahap implementasi perangkat pembelajaran yang telah dikembangkan. Teknik pengumpulan data yang digunakan dalam penelitian ini 1) Validasi Perangkat, digunakan untuk memperoleh tentang validitas perangkat pembelajaran yang dikembangkan dan telah direvisi oleh pembimbing yakni RPP, BAS, LKS, dan THB. 2) Observasi, melakukan pengamatan secara langsung ke objek penelitian untuk melihat dari dekat kegiatan yang dilakukan.

Observasi dilakukan oleh dua orang pengamat di dalam kelas untuk mengamati keterlaksanaan sekenario di dalam RPP, aktivitas siswa, aspek sikap sosial siswa, aspek keterampilan, dan kendala-kendala yang mungkin terjadi. 3) Angket, digunakan untuk mengumpulkan data tentang respon siswa terhadap pembelajaran. Angket ini diberikan pada hari terakhir penelitian. 4) Pemberian Tes, digunakan untuk mengetahui penguasaan terhadap tujuan pembelajaran pada aspek pengetahuan. Tes dilakukan dua kali, yaitu sebelum pembelajaran (pre test) dan sesudah pembelajaran (post test).

Validitas perangkat pembelajaran yang dikembangkan ditentukan berdasarkan hasil penilaian oleh pakar. Data hasil penilaian dianalisis, selanjutnya disesuaikan dengan kriteria penilaian perangkat pembelajaran yang disajikan pada Tabel 1 .

Tabel 1. Kriteria Pengkategorian Penilaian Perangkat Pembelajaran (Arikunto, 2002).

\begin{tabular}{|c|c|}
\hline Interval Skor & Kategori Penilaian \\
\hline $3,5 \leq \mathrm{P} \leq 4,0$ & Baik/ Sangat Valid \\
\hline $2,5 \leq \mathrm{P}<3,5$ & Cukup Baik/ Valid \\
\hline $1,5 \leq \mathrm{P}<2,5$ & Kurang Baik/ Tidak Valid \\
\hline $1,0 \leq \mathrm{P}<1,5$ & Tidak Baik/ Sangat Tidak Valid \\
\hline
\end{tabular}

Tingkat reliabilitas persen kecocokan dihitung menggunakan analisis statistik percentage of agreement (Watkins dan Pacheco, 2001). Dengan kriteria sebagai berikut:

$\begin{array}{lll}\mathrm{R}<40 \% & = & \text { Tidak Baik } \\ 40 \%<\mathrm{R}<60 \% & = & \text { Cukup Baik } \\ 60 \%<\mathrm{R}<75 \% & = & \text { Baik } \\ \mathrm{R}>75 \% & = & \text { Sangat Baik }\end{array}$


Hasil belajar siswa dianalisis dengan menghitung ketuntasan indikator, dan ketuntasan individual dengan menggunakan rumus:

Kindikator $=\frac{\Sigma \text { ketercapaian tiap indikator }}{\Sigma \text { skor indikator dalam KD }} \times 100 \%$

Suatu indikator dikatakan tuntas apabila $\geq 75 \%$ siswa mencapai ketuntasan indikator (Tim BSNP, 2007).

Kindividual $=\frac{\Sigma \text { skor yang diperoleh siswa }}{\Sigma \text { skor maksimum }} \times 100 \%$

Hasil belajar siswa dapat dikatakan tuntas belajarnya secara individu apabila memenuhi Kriteria Ketuntasan Minimal (KKM) pada mata pelajaran Kimia. KKM Kimia kelas X di SMA Trimurti Surabaya sebesar 70.

Data hasil tes aspek pengetahuan awal dan akhir dilakukan analisis gain ternormalisasi yang dirumuskan (Hake, 1999). Sebagai berikut:

$$
g=\frac{\left(S_{\text {post }}\right)-\left(S_{\text {pre }}\right)}{100 \%-\left(S_{\text {pre }}\right)}
$$

Keterangan:

$$
\begin{aligned}
\mathrm{g}_{\text {(gain) }}= & \text { peningkatan hasil belajar } \\
\mathrm{S}_{\text {pre }}= & \text { rata-rata pretest } \text { atau kemampuan awal } \\
& (\%) \\
\mathrm{S}_{\text {post }}= & \text { rata-rata post test } \text { atau kemampuan akhir }
\end{aligned}
$$

Klasifikasikan gain sebagai berikut:

$$
\begin{array}{ll}
\text { g-tinggi } & :(\mathrm{g})>0,7 ; \\
\text { g-sedang } & : 0,7>(\mathrm{g})>0,3 \\
\text { g-rendah } & :(\mathrm{g})<0,3
\end{array}
$$

\section{HASIL PENELITIAN DAN DISKUSI}

Proses belajar dan mengajar dalam kimia diperlukan penekanan pada aspek multiple representasi. Upaya penggunaan aspek multiple representasi dalam proses pembelajaran dapat dikombinasikan dengan menggunakan model pembelajaran kooperatif tipe STAD. Hasil penelitian diuraikan sebagai berikut:

\section{A. Kualitas Perangkat Pembelajaran}

1. Hasil Validasi Perangkat Pembelajaran

Hasil penilaian perangkat pelajaran RPP, BAS, dan LKS memeperoleh nilai rata-rata dengan kategori sangat baik, begitu juga hasil penilaian THB yang menunjukkan aspek isi dan bahasa dalam kategori valid dan dapat dipahami, hal ini menunjukkan perangkat pembelajaran yang dikembangkan layak digunakan sebagai panduan guru dalam meningkatkan hasil belajar siswa pada pokok bahasan reaksi reduksi oksidasi di kelas X SMA. Rata-rata hasil validasi perangkat pembelajaran dapat dilihat pada Tabel 1 .
Tabel 1. Hasil Validasi Perangkat Pembelajaran

\begin{tabular}{|c|c|c|c|c|}
\hline No & $\begin{array}{c}\text { Perangkat } \\
\text { Pembelajaran }\end{array}$ & $\begin{array}{c}\text { Rata2 } \\
\text { Penilaian }\end{array}$ & Kategori \\
\hline 1. & RPP & 3,76 & Sangat Baik \\
\hline 2. & BAS & 3,67 & Sangat Baik \\
\hline 3. & LKS & 3,69 & Sangat Baik \\
\hline \multirow{2}{*}{ No } & $\begin{array}{c}\text { Perangkat } \\
\text { Pembelajaran }\end{array}$ & $\begin{array}{c}\text { Rata2 } \\
\text { Penilaian }\end{array}$ & Kategori \\
\cline { 3 - 4 } & Isi & Bahasa & \\
\hline 4. & THB & 3,88 & 3,37 & $\begin{array}{c}\text { Valid dan } \\
\text { dapat } \\
\text { dipahami }\end{array}$ \\
\hline
\end{tabular}

Reliabilitas terhadap penilaian perangkat pembelajaran (RPP, BAS, LKS, dan THB) menunjukkan reliabilitas $\geq 75 \%$ hal ini menunjukkan bahwa persentase kecocokan penilaian antara pengamat memiliki kategori sangat baik dan reliabel (Watkins dan Pacheco, 2001).

\section{B. Hasil Implementasi Perangkat Pembelajaran \\ 1. Keterlaksanaan RPP}

Aspek-aspek yang diamati pada keterlaksanaan RPP dengan model pembelajaran kooperatif tipe STAD berbasis multiple representasi meliputi kegiatan pendahuluan, kegiatan inti, penutup, dan pengolahan kelas. Hasil pengamatan terhadap RPP dan keterlaksanaannya dapat dilihat pada Gambar 1 .

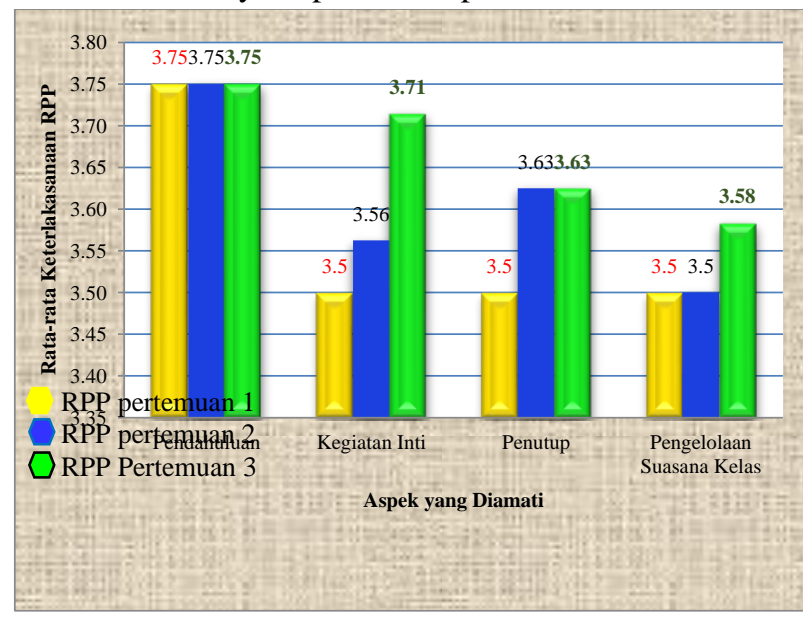

Gambar 1. Rata-Rata Keterlaksanaan RPP Setiap Pertemuan

Hasil rata-rata terhadap keterlaksanaan RPP terhadap ke empat aspek sebesar 3,59 dengan kategori baik. Nilai reliabilitas rata-rata yang diperoleh sebesar 93,61\%. Pengamatan terhadap keterlaksanaan RPP yang diamati pada tiap-tiap aspek (pendahuluan, kegiatan inti, dan penutup) menunjukkan aspek keterlaksanaan $100 \%$. Hal ini menunjukkan bahwa RPP dengan menggunakan pembelajaran kooperatif tipe STAD berbasis multiple representasi terlaksana dengan baik oleh guru, dan siswa pun sudah terlibat aktif dalam kegiatan pembeljaran. 


\section{Aktivitas Siswa}

Aktivitas siswa selama pembelajaran menunjukkan bahwa frekuensi aktivitas siswa di dalam kelas dalam pembelajaran lebih mendominasi dibandingkan aktivitas guru. Aktivitas ini terlihat dari rata-rata hasil aktivitas siswa sebesar $81,11 \%$. Hasil ini diperoleh dari pengurangan aktivitas yang lebih cenderung dilakukan siswa dikurangi aktivitas yang dilakukan oleh guru dan perilaku yang tidak relevan. Hasil ini menandakan dalam kegiatan pembelajaran siswa berperan aktif, sementara peran guru mengarahkan siswa atau berperan sebagai fasilisator dan motivator. Pembelajaran kooperatif dapat berlangsung apabila adanya will dan skill dari siswa, yaitu kemauan dan keterampilan untuk kerja sama (Lie, 2005). Data aktivitas siswa secara visual disajikan pada Gambar 2



$\square 1 \square 2 \square 3 \square 4 \square 5 \square 6 \square 7 \square 8 \square 9$

Gambar 2. Grafik Aktivitas Siswa

Pembelajaran kooperatif terbukti mampu meningkatkan aktivitas siswa, hal ini dibuktikan dari hasil penelitian yang menyatakan bahwa penerapan pembelajaran dengan pendekatan kooperatif tipe STAD dapat meningkatkan aktivitas dan hasil belajar siswa . (Auliah. $d k k, 2009$ ).

\section{Respon Siswa}

Respon siswa terhadap komponen materi/ isi pelajaran, LKS, buku siswa, cara mengajar guru, suasana belajar, dan tahapan-tahapan yang diarahkan guru dalam proses pembelajaran diperoleh respon siswa sebesar $91,40 \%$ menyatakan menarik. Respon siswa terhadap komponen materi/ isi pelajaran, LKS, buku siswa, cara mengajar guru, suasana belajar yang dilatihkan, dan cara guru mengajar diperoleh respon siswa sebesar 89,03\% menyatakan baru. Respon siswa terhadap komponen bahasa dalam buku, materi/ isi buku, contoh-contoh soal, LKS, serta petunjuk kegiatan dalam LKS sebesar 92,26\% siswa memberikan respon mudah untuk dipahami oleh mereka. Respon siswa terhadap komponen penjelasan guru saat pembelajaran berlangsung, bimbingan guru saat menemukan konsep melalui percobaan, dan bimbingan guru pada saat menyelesaikan LKS sebesar $91,40 \%$ jelas, dalam arti siswa mengerti apa yang disampaikan oleh guru selama proses pembelajaran berlangsung. Respon siswa terhadap penggunaan pembelajaran kooperatif tipe STAD berbasis multiple representasi dengan uruturutan memotivasi dan menyampaikan tujuan pembelajaran, menyampaikan informasi, mengorganisasikan siswa ke dalam kelompokkelompok belajar, membimbing kelompok bekerja dan belajar, evaluasi dan memberikan penghargaan sebesar 94,09\% siswa menyatakan baik. Respon minat siswa untuk mengikuti pelajaran dengan menggunakan model pembelajaan kooperatif berbasis multiple representasi untuk materi lain $100 \%$ siswa menyatakan berminat.

Hasil respon siswa terhadap pembelajaran Kimia yang menggunakan model pembelajaran kooperatif berbasis multiple representasi secara visual ditampilkan dalam bentuk diagram pada Gambar 3 .

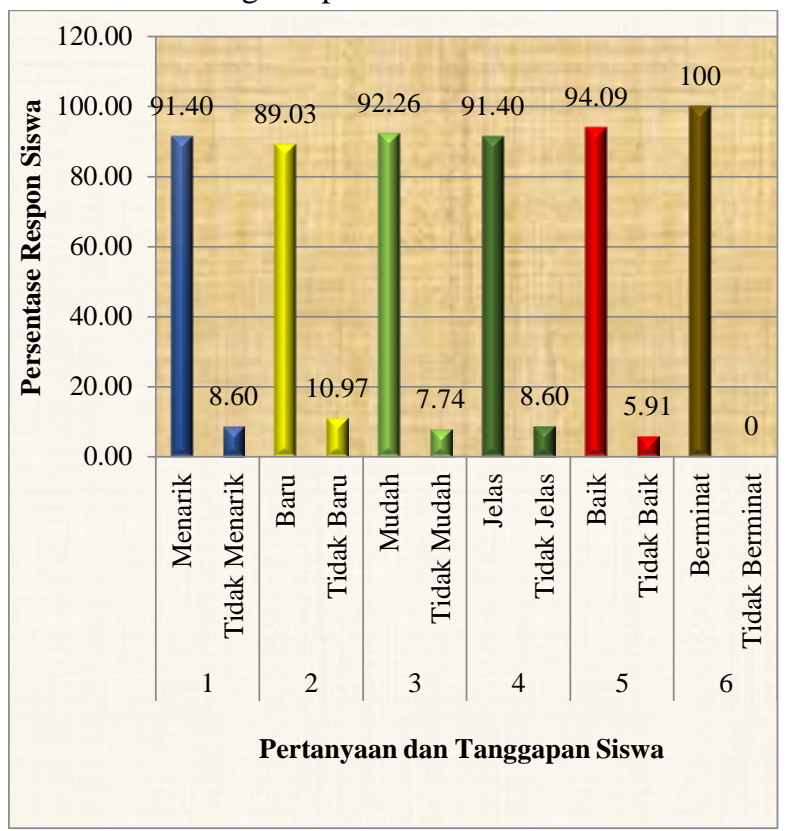

Gambar 3. Respon Siswa Terhadap Pembelajaran yang Menggunakan Model Pembelajaran Kooperatif Tipe STAD berbasis Multiple Representasi.

4. Hasil Belajar

a. Hasil Belajar Aspek Pengetahuan

Rata-rata hasil belajar siswa pada aspek pengetahuan yaitu 82,86 , dengan rata-rata peningkatan sebesar 0,79 atau $79 \%$. Seluruh siswa menunjukkan ketuntasan hasil belajar siswa dengan skor peningkatan yang tinggi (Hake, 1999).. Perhitungan skor peningkatan ( $N$-Gain score) hasil belajar siswa pada aspek pengetahuan dapat dilihat pada Tabel 2. 
Tabel 2. Perhitungan $N$-Gain Score Hasil Belajar Siswa pada Aspek Pengetahuan

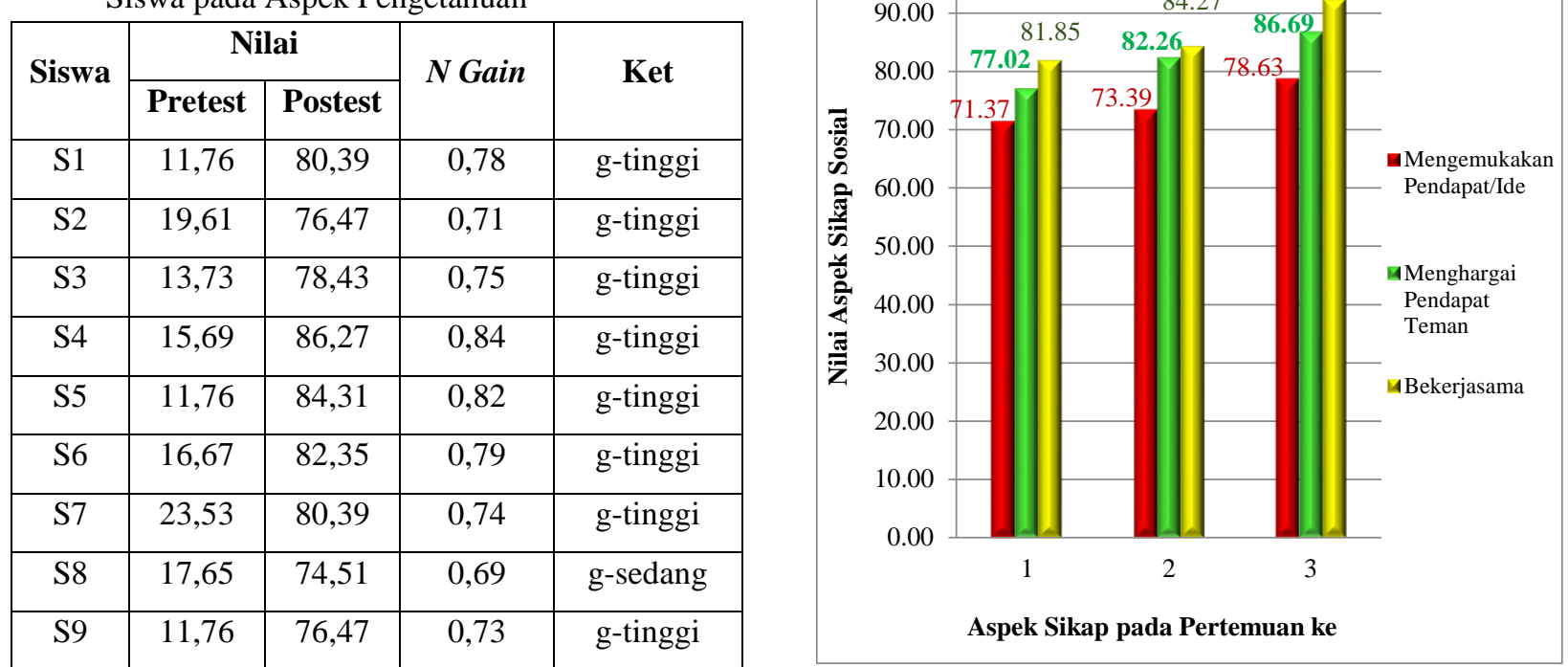

Gambar 4. Aspek Sikap Sosial Siswa

Pembelajaran dengan menggunakan model pembelajaran kooperatif tipe STAD menunjukkan efektif untuk mengembangkan aspek sikap sosial pada siswa, hal ini sesuai dengan tujuan dari pembelajaran kooperatif yaitu hasil belajar akademik, penerimaan terhadap perbedaan individu, dan pengembangan keterampilan sosial. (Ibrahim. $d k k, 2005)$. Keefektifan pembelajaran kooperatif tipe STAD terhadap aspek sikap sosial siswa, juga dibuktikan dari hasil penelitian yang menyatakan bahwa pembelajaran kooperatif tipe STAD dapat memberikan hasil posiitif terhadap keterampilan sosial siswa dimana siswa memperoleh nilai memuaskan pada tiap aspek keterampilan sosial (komunikasi, kerjasama, dan tanggung jawab), selain itu berdasarkan kegiatan belajar mengajar I, II, dan III keterampilan sosial siswa menunjukkan peningkatan terhadap kategori penilaian (Ulansari dan Yonata, 2012).

Vygotsky menekankan pentingnya peranan lingkungan kebudayaan dan interaksi sosial dalam perkembangan sifat-sifat dan tipe-tipe manusia. Menurut Vygotsky, siswa belajar melalui interaksi dengan orang dewasa dan teman sebaya yang lebih mampu. Interaksi sosial ini memacu terbentuknya ide baru dan memperkaya perkembangan intelektual siswa. Pada setting kooperatif, siswa dihadapkan pada proses berpikir teman sebaya mereka. Tutorial oleh teman yang lebih kompeten akan sangat efektif dalam mendorong pertumbuhan daerah perkembangan proximal (Zone of Proximal Development) anak (Slavin, 2008).

Vygotsky yakin bahwa tujuan belajar akan tercapai jika anak belajar menyelesaikan tugas-tugas yang belum dipelajari tetapi tugas-tugas tersebut masih berada dalam daerah perkembangan terdekat mereka. Daerah perkembangan terdekat adalah tingkat 
perkembangan sedikit di atas tingkat perkembangan orang saat ini. Zone of Proximal Development (ZPD) adalah jarak antara tingkat perkembangan aktual, yang ditentukan melalui penyelesaian masalah secara mandiri dan tingkat perkembangan potensial anak, yang ditentukan melalui pemecahan masalah dengan bimbingan orang dewasa atau teman sebaya. Menurut Vygotsky, pada saat siswa bekerja di dalam daerah perkembangan terdekat mereka, tugas-tugas yang tidak dapat mereka selesaikan sendiri akan dapat mereka selesaikan dengan bimbingan orang dewasa atau teman sebaya (Slavin, 2008).

\section{c. Hasil Belajar Aspek Keterampilan}

Hasil penilaian aspek keterampilan menunjukkan $100 \%$ siswa memiliki keterampilan yang baik, dengan rata-rata nilai 81,12. Kegiatan dengan melakukan kegiatan praktik kerja dilaboratorium selama proses pembelajaran diharapkan mempu membuat siswa terlatih dalam keterampilan yang bersifat ilmiah.

Kegiatan pembelajaran seperti yang dilaksanakan dalam pembelajaran ini, diharapkan mampu memenuhi harapan dari pelaksanaan kurikulum 2013 yaitu adanya peningkatan dan keseimbangan antara kemampuan dan pengetahuan untuk hidup secara layak dari peserta didik yang meliputi aspek sikap, pengetahuan dan keterampilan (Mendikbud, 2013).

\section{Kendala-Kendala Selama Kegiatan belajar Mengajar}

Kendala-kendala yang dialami selama proses pembelajaran dominan dijumpai pada pertemuan pertama dan dapat diatasi pada pertemuan berikutnya.

Kendala-kendala yang dihadapi peneliti selama proses pembelajaran beserta alternatif solusinya dapat disajikan pada Tabel 3 .

Tabel 3. Kendala-Kendala Selama Pembelajaran Berlangsung dan Solusinya.

\begin{tabular}{|l|l|l|}
\hline No & \multicolumn{1}{|c|}{ Jenis Kendala } & \multicolumn{1}{|c|}{ Solusi } \\
\hline 1 & $\begin{array}{l}\text { Keterbatasan waktu } \\
\text { dalam pelaksanaan } \\
\text { pembelajaran }\end{array}$ & $\begin{array}{l}\text { Lebih memperhatikan } \\
\text { alokasi waktu dan lebih } \\
\text { memaksimalkan pada } \\
\text { kegiatan yang penting }\end{array}$ \\
\hline \multirow{2}{*}{2} & $\begin{array}{l}\text { Beberapa siswa } \\
\text { mengandalkan } \\
\text { siswa yang lain } \\
\text { untuk melakukan } \\
\text { unjuk kerja }\end{array}$ & $\begin{array}{l}\text { Guru mengarahkan } \\
\text { siswa untuk membagi } \\
\text { porsi kerja secara } \\
\text { bergantian (adil) }\end{array}$ \\
\hline \multirow{2}{*}{3} & $\begin{array}{l}\text { Siswa belum } \\
\text { percaya diri untuk } \\
\text { henyampaikan } \\
\text { ataupun kerjanya untuk } \\
\text { bertanya dan } \\
\text { menyampaikan } \\
\text { pendapat }\end{array}$ & $\begin{array}{l}\text { Guru memberi motivasi } \\
\text { kepada siswa untuk } \\
\text { berani tampil tanpa } \\
\text { khawatir salah ataupun } \\
\text { benar }\end{array}$ \\
\hline
\end{tabular}

\section{KESIMPULAN}

Berdasarkan hasil penelitian dapat disimpulkan bahwa perangkat pembelajaran kimia dengan menggunakan model pembelajaran kooperatif tipe STAD berbasis multiple representasi layak untuk digunakan dalam proses pembelajaran

\section{REFERENSI}

Johnstone, A.H. (2000). "Teaching Chemistry Logical or Psylogical". Chemistry Education: Research and Practice in Europe. 1 (1) 9 - 15.

Gilbert, J.K and Treagust, D.F. (2009). "Introduction: Macro, Submicro and Symbolic Representations and the Relationship Between Them : Key Models in Chemical Education". Multiple Representation in Chemical Education. The Netherlands: Spinger.

Sunyono. (2014). Model Pembelajaran Berbasis Multiple Representasi dalam Membangun Model Mental dan Penguasaan Konsep Kimia Dasar Mahasiswa (Disertasi tidak dipublikasikan). Universitas Negeri Surabaya.

Herawati, R.F., Mulyani, S., dan Redjeki, T. (2013). "Pembelajaran Kimia Berbasis Multipel Representasi Ditinjau dari Kemampuan Awal terhadap Prestasi Belajar Laju Reaksi Siswa SMA Negeri 1 Karanganyar Tahun Pelajaran 2011/2012”. Jurnal Pendidikan Kimia (JPK). 2 (2).

Arikunto, S. (2002). Prosedur Penelitian. Suatu Pendekatan Praktek. Jakarta: Rineka Cipta.

Ratumanan, T.G. (2006). Evaluasi Hasil Belajar yang Relevan dengan Kurikulum Berbasis Kompetensi. Surabaya: Unesa University Press.

Watkins, M.W and Pacheco, M. (2001). "Interobserver Agreement in Behavioral Research: Importance and Calculation". Journal of Behavioral Education, 10 (4) 205 - 212.

Tim BSNP. (2007). Permendiknas Nomor 41 Tahun 2007 Tentang Standar Proses untuk Satuan Pendidikan Dasar dan Menengah. Jakarta: BSNP.

Hake, R.R. (1999). Analyzing Change/Gain Scores. Tersedia http://www.physicsindiana.edu/sdi/AnalyzingChange-Gain. Pdf. Diakses 15 November 2013.

Borich, G.D. (1994). Observational Skill for Effective Teaching. Englewood Cliffs: Merril Publisher.

Lie, A. (2005). Cooperative Learning. Mempraktikan Cooperative Learning di Ruang-Ruang Kelas. Jakarta: Grasindo.

Auliah, Army dan Supriati. (2009). "Penerapan Pembelajaran Siklus Belajar Setting Kooperatif STAD pada Siswa Kelas XI IPA 1 SMA Negeri 1 Sungguminasa (Studi pada Meteri Pokok Laju Reaksi)". Jurnal Chemica 10(1) 28 - 35. 
Ibrahim, M., Rachmadiarti, F., Nur, M., dan Ismono. (2005). Pembelajaran Kooperatif. Surabaya: UNESA-University Press.

Ulansari, I dan Yonata, B. (2012). "Keterampilan Sosial Siswa Melalui Pembelajaran Kooperatif Tipe STAD pada Materi Pokok Larutan Penyangga di SMAN 1 Sumberrejo Bojonegoro". Unesa Journal of Chemical Education 1 (1) 136-
144.

Slavin, R.E. (2008). Psikologi Pendidikan Teori dan Praktik. Jakarta: Indeks.

Mendikbud. (2013). Diklat Guru dalam Rangka Implementasi Kurikulum 2013. Konsep Pendekatan Scientific. Jakarta: Kementrian Pendidikan dan Kebudayaan. 